\title{
Chemical composition and biological activity of Rubus idaeus shoots - a traditional herbal remedy of Eastern Europe
}

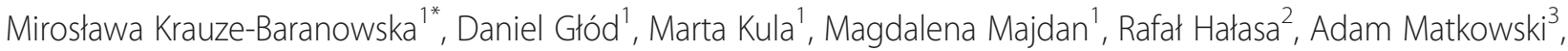
Weronika Kozłowska ${ }^{3}$ and Anna Kawiak ${ }^{4}$

\begin{abstract}
Background: The young shoots of Rubus idaeus are traditionally used as a herbal remedy in common cold, fever and flu-like infections yet there is no research concerning this plant material. The aim of the study was to evaluate the chemical composition and biological properties of raspberry shoots from 11 cultivar varieties.

Methods: The methanol extracts were subjected to chromatographic analysis using HPLC-DAD-ESI-MS, and two-dimensional 'comprehensive' LCXLC techniques. The biological activity of the shoot extract from the 'Willamette' cultivar variety was evaluated. Antioxidant activity was tested using DPPH and phosphomolybdenum assay. Antimicrobial activity was estimated towards 15 strains of human pathogenic bacteria using broth microdilution method. Cytotoxic activity was tested using MTT cell viability assay.

Results: The dominating compounds identified in the shoots of $R$. idaeus were ellagic acid (26.1 - 106.8 mg/100 g) and sanguiin H-6 (139.2 - $633.1 \mathrm{mg} / 100 \mathrm{~g})$. The best separation of compounds present in the analysed polyphenol complex, was achieved by 'comprehensive' LCXLC method using Nucleodur Sphinx RP column in the first dimension and Chromolith Performance column in the second dimension. The shoot extract was found to be a strong antioxidant ( $E_{50} 19.4 \mu \mathrm{g} / \mathrm{ml}$, AAE $427.94 \mathrm{mg} / \mathrm{g}$ ) and displayed the strongest bactericidal properties towards Corynebacterium diphtheriae. The extract revealed higher cytotoxic activity towards the HL-60 cells $\left(I C_{50} 110 \mu \mathrm{g} / \mathrm{ml}\right)$ than HeLa $\left(I C_{50} 300 \mu \mathrm{g} / \mathrm{ml}\right)$.
\end{abstract}

Conclusions: The shoots of $R$. idaeus stand out as a valuable source of sanguiin $\mathrm{H}-6$ and ellagic acid and possess a number of biological properties including antioxidative, antimicrobial and cytotoxic.

Keywords: Rubus idaeus, Shoots, HPLC-DAD-ESI-MS, Comprehensive LCxLC, Biological activity

\section{Background}

The red raspberry - Rubus idaeus L. (Rosaceae) is a species widely known for its edible fruits. Although they are most commonly known as food products, they are also a popular anti-inflammatory and antimicrobial remedy used in traditional medicine in eastern parts of Europe. Although the most common herbal drug in folk medicine is the fruit, the shoots of $R$. idaeus have also been used to treat common cold, fever and flu-like infections [1].

\footnotetext{
* Correspondence: krauze@gumed.edu.pl

'Department of Pharmacognosy with Medicinal Plants Garden, Faculty of Pharmacy with Subfaculty of Laboratory Medicine, Medical University of Gdańsk, Gen. J. Hallera Str. 107, 80-416 Gdańsk, Poland

Full list of author information is available at the end of the article
}

Although much interest has been given to the chemical composition and biological properties of raspberries [2], no similar research concerning raspberry shoots was performed up to date. The raspberry fruit contains a number of phenolic compounds, the predominant being anthocyanins and ellagitannins, accompanied by significantly lower concentrations of flavonoids, phenolic acids and flavan-3ols [2-7]. Ellagitannins are a group of hydrolysable tannins distinctive for the family Rosaceae. The main ellagitannin present in Rubus species is sanguiin $\mathrm{H}-6$, which is accompanied by lambertianin $C$ and other ellagitannins in small quantities [8,9]. Ellagitannins, as well as some flavonoids have also been detected in raspberry leaves $[10,11]$. 
HPLC technique coupled with selective detectors, mainly MS [12], is a method of choice in fast determination of the chemical composition of plant extracts [13]. Additionally, two- dimensional HPLC techniques are a new chromatographic approach enabling more efficient resolution of complex samples of plant origin [14].

The aim of this study was to evaluate the chemical composition and biological properties of the shoots obtained from several varieties of raspberries cultivated in Poland.

\section{Methods}

\section{Plant material}

The tops of young, non-lignified shoots of $11 \mathrm{R}$. idaeus cultivar varieties, namely: 'Benefis', 'Beskid', 'Glen Ample, 'Heritage,' 'Koral', 'Laszka,' 'Polana,' 'Polesie, 'Poranna Rosa', 'Willamette', 'Veten' were collected and identified by Ph. D. Józef Gwozdecki and M. S. Justyna Wójcik from the Department of Pomology, Gene Resources and Nurseries from the Research Institute of Pomology and Floriculture in Skierniewice (Poland). The shoots were dried and powdered. The plants are deposited at the Herbarium of the Medicinal Plants Garden of the Medical University of Gdańsk (Poland) with the following numbers of voucher specimens: 672009 ('Benefis'), 68-2009 ('Beskid'), 69-2009 ('Glen Ample'), 70-2009 ('Heritage'), 71-2009 ('Koral'), 72-2009 ('Laszka'), 73-2009 ('Polana'), 74-2009 ('Polesie'), 75-2009 ('Poranna Rosa'), 76-2009 ('Willamette'), 77-2009 ('Veten').

\section{Sample preparation}

The plant material (5 g) was subjected to a continuous, exhausting extraction in a Soxhlet apparatus (100 h) using chloroform and then methanol. The methanol extract was evaporated to the volume of $50 \mathrm{ml}$ and subjected to chromatographic analysis.

For determining biological activity, a dry extract from $R$. idaeus 'Willamette' variety was prepared by adding water to the methanol extract, which was then evaporated, lyophilised and stored in airtight containers away from the light.

\section{Standard compounds}

Caffeic acid, chlorogenic acid, ellagic acid, gallic acid, salicylic acid, catechin, hyperoside, quercetin, isoquercetin, kaempferol 3-O-galactoside, myricetin and kaempferol were obtained from Fluka (Switzerland). Procyanidin $\mathrm{B}_{1}$, procyanidin $\mathrm{B}_{2}$, quercetin 3-O-glucuronide, quercetin 3-O-rhamnoside and tiliroside were obtained from Extrasynthèse (France). Protocatechuic acid, epicatechin and epigallocatechin were obtained from Sigma (Germany). Sanguiin H-6 was isolated according to the previously described procedure [9].

\section{HPLC system}

To evaluate the phenolic content of the shoots of $R$. idaeus a HPLC-DAD-ESI-MS analysis was performed using a HPLC system consisting of steal wash pump LC-20 AD (2), CBM-20 system controller, column termostat CT0-20 AC, auto-sampler SIL 20 AC, detector UV-VIS (Diode Array Detector), mass spectrometer LCMS-2020 with electrospray ionisation (ESI probe), LabSolution computer software (Shimadzu, Japan).

Parameters of MS detector: Detector voltage $3.5 \mathrm{kV}$, interface voltage $5.0 \mathrm{kV}$, heat block $200^{\circ} \mathrm{C}$, DL temperature $250^{\circ} \mathrm{C}$, nebulising gas flow $\left(\mathrm{N}_{2}\right) 1.5 \mathrm{~L} / \mathrm{min}$, drying gas flow $16 \mathrm{~L} / \mathrm{min}$.

\section{Columns and precolumns}

Discovery HS C18 (150 mm $\times 2.1 \mathrm{~mm}, 3 \mu \mathrm{m})$, Discovery HS C18 (20 $\mathrm{mm} \times 2.1 \mathrm{~mm}, 3 \mu \mathrm{m}) \quad$ (pre-column) (Supelco, USA), Nova-pak C $18(150 \times 3.9 \mathrm{~mm}, 4 \mu \mathrm{m})$ (Waters, USA), Nucleodur Sphinx RP $(50 \mathrm{~mm} \times 1 \mathrm{~mm}$, $5 \mu \mathrm{m}$ ) (Marcherey-Nagel, Germany), Chromolith Flash RP-18e (25 mm $\times 4.6 \mathrm{~mm})$, Chromolith Performance (100 mm × $4.6 \mathrm{~mm})$ (Merck, Germany).

\section{Gradient programs}

Solvents: A - TFA:water (0.1:100, v/v); B - TFA:water: acetonitrile $(0.1: 50: 50, \mathrm{v} / \mathrm{v} / \mathrm{v})$.

I - (percentage of B in $\mathrm{A}+\mathrm{B}$ ): 0 min - $12 \% \mathrm{~B}, 10 \mathrm{~min}$ $20 \%$ B, 30 min - 43\% B, 40 min - 100\% B, 55 min $100 \%$ B, 60 min - 12\% B, 75 min - 12\% B;

II - (percentage of $B$ in $A+B$ ): 0 min - 10\% B, 70 min $56 \% \mathrm{~B}$, conditioning: $74 \mathrm{~min}-100 \% \mathrm{~B}, 84 \mathrm{~min}$ 100\% B, 85 min - 10\% B, 95 min - 10\% B;

III - (percentage of B in $A+B$ ): 0 min - 0\% B, 6 min - 0\% B, $6.1 \mathrm{~min}-10 \% \mathrm{~B}, 14 \mathrm{~min}-10 \% \mathrm{~B}, 14.1 \mathrm{~min}-15 \%$ B, 18 min - 15\% B, 18.1 min 17\% B, 20 min - 17\% B, 20.1 min - 20\% B, 22 min - 20\% B, 22.1 min $21 \%$ B, 24 min - 21\% B, 24.1 min - 23\% B, 24, $30 \min -23 \%$ B, $30.1 \min -25 \%$ B, $32 \min -25 \%$ B, 32.1 min - 27\% B, 34 min $-27 \%$ B, $34.1-28 \%$ B, $36 \min -28 \%$ B, $36.1 \min -29 \%$ B, 40 min - 29\%, $40.1 \mathrm{~min}-31 \%$ B, $42 \mathrm{~min}-31 \%$ B, $42.1 \mathrm{~min}-34 \%$ B, 46 min - 34\% B, 46.1 min - 35\% B, 52 min $-35 \%$ B, $52.1 \mathrm{~min}-45 \%$ B, $60 \mathrm{~min}-45 \%$ B, $60.1 \mathrm{~min}-$ $55 \% \mathrm{~B}, 70 \mathrm{~min}-55 \% \mathrm{~B}$, conditioning: $70.1 \mathrm{~min}-$ $100 \%$ B, $84 \min -100 \%$ B, $84.1 \mathrm{~min}-0 \%$ B, $95 \min -0 \%$.

\section{Conditions of one-dimensional HPLC separation}

Discovery HS C18 $(150 \mathrm{~mm} \times 2.1 \mathrm{~mm}, 3 \mu \mathrm{m})$, Discovery HS C18 (20 mm $\times 2.1 \mathrm{~mm}, 3 \mu \mathrm{m})$ (pre-column), gradient program $\mathrm{I}, \mathrm{T}=32^{\circ} \mathrm{C}, \mathrm{v}=0.3 \mathrm{ml} / \mathrm{min}, \mathrm{v}_{\text {injection }}=1 \mu \mathrm{l}, \mathrm{UV}$ $\lambda=280 \mathrm{~nm}$. 


\section{Conditions of two-dimensional HPLC separation First dimension}

Nucleodur Sphinx RP (50 mm $\times 1 \mathrm{~mm}, 5 \mu \mathrm{m})$ column, gradient program II, $\mathrm{T}=20^{\circ} \mathrm{C}, \mathrm{v}=50 \mu \mathrm{l} / \mathrm{min}, \mathrm{v}_{\text {injection }}=$ $0.4 \mu \mathrm{l}$, UV $\lambda=254 \mathrm{~nm}$.

\section{Second dimension}

Chromolith Flash RP-18e $(25 \mathrm{~mm} \times 4.6 \mathrm{~mm})$, Chromolith Performance $(100 \mathrm{~mm} \times 4.6 \mathrm{~mm})$ columns, gradient program III, $\mathrm{T}=20^{\circ} \mathrm{C}, \mathrm{v}=6 \mathrm{ml} / \mathrm{min}$, modulation time $=2 \mathrm{~min}$, sampling time $=6.25 \mathrm{~Hz}, \mathrm{v}_{\text {loop }}=50 \mu \mathrm{l}$, UV $\lambda=254 \mathrm{~nm}$. ESI-MS in positive and negative mode.

\section{Qualitative analysis method validation}

The developed HPLC method for purposes of quantitative analysis was validated by determining the calibration curves, linear regression, limit of quantitation (LOQ) and recovery of analysed compounds, which were estimated according to the guidlines of Validation of Chromatographic Methods by Food and Drug Administration, Center for Drug Evaluation and Research http://www.fda.gov/ downloads/Drugs/Guidances/UCM134409.pdf (Table 1).

The calibration curves were determined for the standard compounds. Linearity for the working concentrations of the standard compounds was evaluated by determining the correlation coefficient. Stock solutions of standard compounds were diluted in methanol (1 $\mathrm{mg} / \mathrm{ml})$. Regression curves were determined basing on the analysis of plot of peak area for the following concentrations of compounds $(\mu \mathrm{g} / \mathrm{ml})$ :

- gallic acid and chlorogenic acid: 6.25, 12.5, 25, 50, 100

- catechin, epicatechin, isoquercetin: 3.125, 6.25, 12.5, 25,100

- ellagic acid, hyperoside: 3.125, 6.25, 12.5, 25, 50, 100

- procyanidin $\mathrm{B}_{1}$ and $\mathrm{B}_{2}: 10,20,40,80,150,300$

- sanguiin H-6: 62.5, 125, 250, 500, 1000.
Regression equations and correlation coefficients are presented in Table 1. LOQ was established as the concentration of the standard compound equalling $10 \times$ of the baseline noise. Recovery was determined through adding the standard compounds in the quantities corresponding $50 \%, 75 \%$ and $125 \%$ of their content in the plant material, and calculating the percentage of recovery from the median sum of compounds in the plant material as well as the added quantities of standard compounds. Concentrations of quercetin 3-O-glucuronide and an unknown quercetin pentoside were calculated on isoquercetin (Table 1).

\section{Free radical scavenging ability (FRS) in DPPH assay}

The experimental procedure was performed according to Brand-Williams et al. [15]. $150 \mu \mathrm{l}$ of $R$. idaeus 'Willamette' extract was mixed in a 96-well plate (Greiner, Germany) with $0.2 \mathrm{mM}$ methanol solution of DPPH (Sigma). The concentrations of the extract in the reaction mixture were the following: $1,2.5,5.0,10,25.0$, $50.0,100,250$, and $500 \mu \mathrm{g} / \mathrm{ml}$. The disappearance of $\mathrm{DPPH}$ was monitored spectrophotometrically at $517 \mathrm{~nm}$ using microQuant microplate reader (Biotek, USA), during $30 \mathrm{~min}$ incubation at room temperature. Free radical scavenging capacity (FRS) was calculated by the following equation: $\mathrm{FRS}(\%)=\left(100-\mathrm{ABS}_{\text {sample }} / \mathrm{ABS}_{\mathrm{DPPH}}\right) \times 100$, where Abs sample $=$ Abs measured - Abs control (i.e., absorbance of the sample tested without DPPH). From the obtained values, the dose response curve was created, using nonlinear regression module of GraphPad Prism software, followed by calculation of the $\mathrm{EC}_{50}$ (defined as the concentration of sample at which $50 \%$ of maximum scavenging activity was recorded).

\section{Reducing power using phosphomolybdenum assay}

The modified method of Prieto et al. was used [16]. The shoot extract $(200 \mu \mathrm{l})$ was mixed with the reagent solution

Table 1 Validation parameters for the HPLC method for quantitative analysis of phenolic compounds in the shoots of R. idaeus

\begin{tabular}{|c|c|c|c|c|}
\hline Compound & Calibration curve & $r^{2}$ & LOQ $[\mu \mathrm{g} / \mathrm{ml}]$ & Recovery \\
\hline Gallic acid & $y=0.00022 x$ & 0.9998 & 3.6 & $110.13 \pm 3.86$ \\
\hline Chlorogenic acid & $y=0.000265 x+1.666$ & 0.99972 & 4.2 & $107.44 \pm 5.76$ \\
\hline Catechin & $y=0.000409 x-0.222$ & 0.99955 & 5.7 & $94.83 \pm 4.98$ \\
\hline Epicatechin & $y=0.000331848 x-1.007753$ & 0.99995 & 2.6 & $101.25 \pm 6.02$ \\
\hline Isoquercetin & $y=0.000485465 x-0.0266931$ & 0.99997 & 1.25 & $103.07 \pm 3.98$ \\
\hline Ellagic acid & $y=0.000300 x+1.909$ & 0.99964 & 2.32 & $102.85 \pm 2.98$ \\
\hline Hyperoside & $y=0.000413836 x-0.29958$ & 0.99995 & 1.5 & $105.62 \pm 2.43$ \\
\hline Procyanidin $\mathrm{B}_{1}$ & $y=0.000711836 x-2.04033$ & 0.99996 & 17.1 & $105.67 \pm 4.15$ \\
\hline Procyanidin $B_{2}$ & $y=0.000896 x-2.34$ & 0.9999 & 12.6 & $96.42 \pm 3.58$ \\
\hline Sanguiin $\mathrm{H}-6$ & $y=0.00109921 x+4.56879$ & 0.99997 & 7.1 & $95.82 \pm 5.23$ \\
\hline
\end{tabular}

$r^{2}$ - linear regression; LOQ - limit of quantitation. 
$(1.8 \mathrm{ml})$ containing ammonium molybdate $(4 \mathrm{mM})$, sodium phosphate $(28 \mathrm{mM})$ and sulfuric acid $(600 \mathrm{mM})$. The final tested concentrations were the following: 2.5, $5.0,10.0,25.0,50.0 \mu \mathrm{g} / \mathrm{ml}$. The reaction mixture was incubated in a water bath shaker at $90^{\circ} \mathrm{C}$ for $90 \mathrm{~min}$. After cooling, the absorbance of the green phosphomolybdenum complex was measured at $695 \mathrm{~nm}$ against a blank (where the extract was replaced by $50 \%$ aqueous methanol). The reducing power was compared to the standard antioxidant - ascorbic acid and expressed as ascorbic acid mass equivalents (AAE) (mg/g). The reducing power is calculated as linear dose response slope ratio of extract and ascorbic acid: $\mathrm{RP}=$ slope-sample/slope-ascorbic acid.

\section{Test microorganisms}

\section{Gram-positive bacteria}

$\beta$-hemolytic Streptococcus group A,B,G, Streptococcus pneumoniae (clinical isolates), Corynebacterium diphtheriae, Enterococcus faecalis (collection of the Department of Pharmaceutical Microbiology, Medical University of Gdańsk), Staphylococcus aureus ATCC9027, Staphylococcus epidermidis ATCC14990, Bacillus subtilis ATCC6633, Clostridium sporogenes PCM2486.

\section{Gram-negative bacteria}

Klebsiella pneumoniae (clinical isolate), Neisseria meningitidis PCM2586, Moraxella catarrhalis PCM2340, Haemophilus influenzae PCM2340, Helicobacter pylori ATCC10231. Clinical isolates were obtained from St. Adalbert Specialist Hospital in Gdańsk (Independent Public Health Care Facility in Gdańsk, Poland).

\section{Antibacterial assay}

Bacterial cultures were prepared in accordance with literature data by transferring cells from the stock cultures to tubes with adequate broth [17-20], and incubated for 2448 hours at $37^{\circ} \mathrm{C}$. The cultures were diluted to an optical density corresponding to $10^{5}$ colony forming units per $\mathrm{ml}$ (CFU/ml). For H. pylori, the inoculum was prepared from colonies grown on TSA (Becton Dickinson, USA) supplement with $5 \%$ sheep blood agar plates with final concentration of approximately $10^{5} \mathrm{CFU} / \mathrm{ml}[21]$.

Minimum inhibitory concentration (MIC) was determined by broth microdilution technique using 96-well plates. Dry shoot extract was dissolved in water to concentration of $120 \mathrm{mg} / \mathrm{ml}$. Each well was filled with $100 \mu \mathrm{l}$ of broth, and the shoot extract was added to the wells and diluted in a geometric progression by transferring $100 \mu \mathrm{l}$ of the solution to the next well (concentrations from 120 to $0.06 \mathrm{mg} / \mathrm{ml}$ ), followed by adding the microbial suspensions $(100 \mu \mathrm{l})$ of the tested bacterial strains to each well. Ampicillin was used as a reference compound. The plates were incubated in the conditions appropriate for each bacterium [17-20].
After incubation a visual observation of growth was performed. The MIC was established as the lowest sample concentration that prevented visible growth [22]. In addition $100 \mu \mathrm{l}$ of suspension from each well without visible growth was inoculated (48 hours) on an agar plate to check bacterial viability. MBC (minimal bactericidal concentration) was defined as the minimum concentration of extract required to kill the bacteria in the medium. For determining Helicobacter pylori viability Christiansen broth (home-made, urease test $50 \mu \mathrm{l}$ ) was used.

\section{MTT cell viability assay}

The cytotoxic assay was conducted using human dermal fibroblasts, human promyelocytic leukemia cell line (HL60) (Department of Drug Technology and Biochemistry, Technical University of Gdańsk, Poland) and human cervical cancer cell line (HeLa) (Department of Histology and Immunology, Medical University of Gdańsk, Poland).

The viability of the cells was determined using the MTT assay. The cells were transferred to 96 well plates, in concentration of $10^{5} /$ well, and incubated overnight $\left(\mathrm{T}=37^{\circ} \mathrm{C}\right)$ in the presence of $5 \% \mathrm{CO}_{2}$. Cells were then treated for 24 hours with $R$. idaeus 'Willamette' shoot extract $(0-500 \mu \mathrm{g} / \mathrm{ml})$. MTT (3-(4,5-dimethylthiazol-2yl)-2,5-diphenyltetrazolium bromide) was added directly to the medium $(1,2 \mathrm{mM})$ and cells were further incubated for 3 hours, followed by DMSO lysis. The absorbance of the formazan solution was measured at $\lambda=$ $570 \mathrm{~nm}$ with a plate reader [23]. The values were then compared with control groups and survivability was calculated from the following equation: survivability percentage $=\left(\mathrm{A}_{\text {sample }}-\mathrm{A}_{\text {background }}\right) /\left(\mathrm{A}_{\text {control }}-\mathrm{A}_{\text {background }}\right)$ $\times 100$, A-absorbance, - and half maximal inhibitory concentration $\mathrm{IC}_{50}$ was calculated.

\section{Data analysis}

For dose response curve fitting in the DPPH assay and linear function formula of dose response in phosphomolybdenum assay analysis of variance (ANOVA), Tukey's post-choc test were performed (GraphPad Prism 5 Pad Software Inc, La Jolla, USA).

\section{Results and discussion}

HPLC-DAD-ESI-MS analysis

In preliminary HPLC-DAD-ESI-MS separations of the mixture of 21 standard compounds, a Nova-pak C 18 column $(150 \times 3.9 \mathrm{~mm}, 4 \mu \mathrm{m})$ and several gradient elution programmes, varying in gradient profiles and concentration of a mixture of TFA:water:acetonitrile $(0.1: 50: 50, \mathrm{v} / \mathrm{v} / \mathrm{v})$ in $0.1 \%$ TFA aqueous solution, at different $t_{G}$ values, were used. However, it was not possible to obtain resolution of all standard compounds. The best separation of 20 from the 21 standards (isoquercetin and quercetin 3-O-glucuronide not resolved) was achieved 
with Discovery HS C18 column connected to Discovery HS C18 precolumn and gradient elution program I, of an increasing concentration of a mixture of TFA:acetonitrile:water $(0.1: 50: 50, \mathrm{v} / \mathrm{v} / \mathrm{v})$, from $12 \%$ to $43 \%$, in a $0.1 \%$ TFA aqueous solution (Figure 1 ).

Applying the conditions of optimised HPLC-DADESI-MS method, the methanol shoot extracts from 11 cultivar varieties of $R$. idaeus were analysed (Figure 2). Phenolic compounds were identified by comparing their UV spectra and retention time values $\left(t_{R}\right)$ to that of the standard compounds and by comparison of their mass spectra with literature data (Table 2) [24-29].

The dominant compounds present in the analysed shoots of $R$. idaeus were ellagic acid and sanguiin H-6 while the other compounds - phenolic acids, flavonoids and flavan3-ols occurred in much lower concentrations (Figure 2).

From phenolic acids, the presence of gallic acid, protocatechuic acid, chlorogenic acid, caffeic acid and ellagic acid was revealed. Among the chromatographically identified flavonoids, hyperoside, quercetin 3-O-glucuronide, isoquercetin, kaempferol 3-O-galactoside, myricetin, tiliroside, quercetin 3-O-rhamnoside and kaempferol were recognised. The identified flavan-3-ols comprised monomeric catechin and epicatechin, as well as dimeric proanthocyanidins - procyanidin $B_{1}$ and $B_{2}$ (Figure 2, Table 2). These compounds have been previously identified in red and black raspberry fruits, as well as raspberry leaves $[2-7,10,11]$.

Since the separation of isoquercetin and quercetin 3O-glucuronide was not possible in the optimised HPLC conditions, both compounds were identified by the SIM technique. Moreover, by using the SIM technique, the peak observed at $t_{R} 25.5$ min was tentatively identified as an unknown quercetin pentoside (Table 2). Peaks observed at $t_{R} 16.7$ - 19.7 min were identified as ellagitannins. In accordance with UV spectra $\left(\lambda_{\max } 251 \mathrm{~nm}\right)$ and $\mathrm{m} / \mathrm{z}$ values of deprotonated molecules the peaks were identified as: two lambertianin $C$ isomers $\left(t_{R}=17.4 \mathrm{~min}\right.$ and $19.5 \mathrm{~min})$, sanguiin $\mathrm{H}-2\left(\mathrm{t}_{\mathrm{R}}=19.7 \mathrm{~min}\right)$, two sanguiin $\mathrm{H}-10$ isomers $\left(t_{R}=16.7 \mathrm{~min}\right.$ and $\left.19.7 \mathrm{~min}\right)$ and casuarictin/potentillin $\left(t_{R}=18.4 \mathrm{~min}\right.$ ) (Figure 2, Table 2$)$. These ellagitannins have been previously described as constituents of raspberry fruits and leaves, as well as in other species from the genus Rosaceae [24-29].

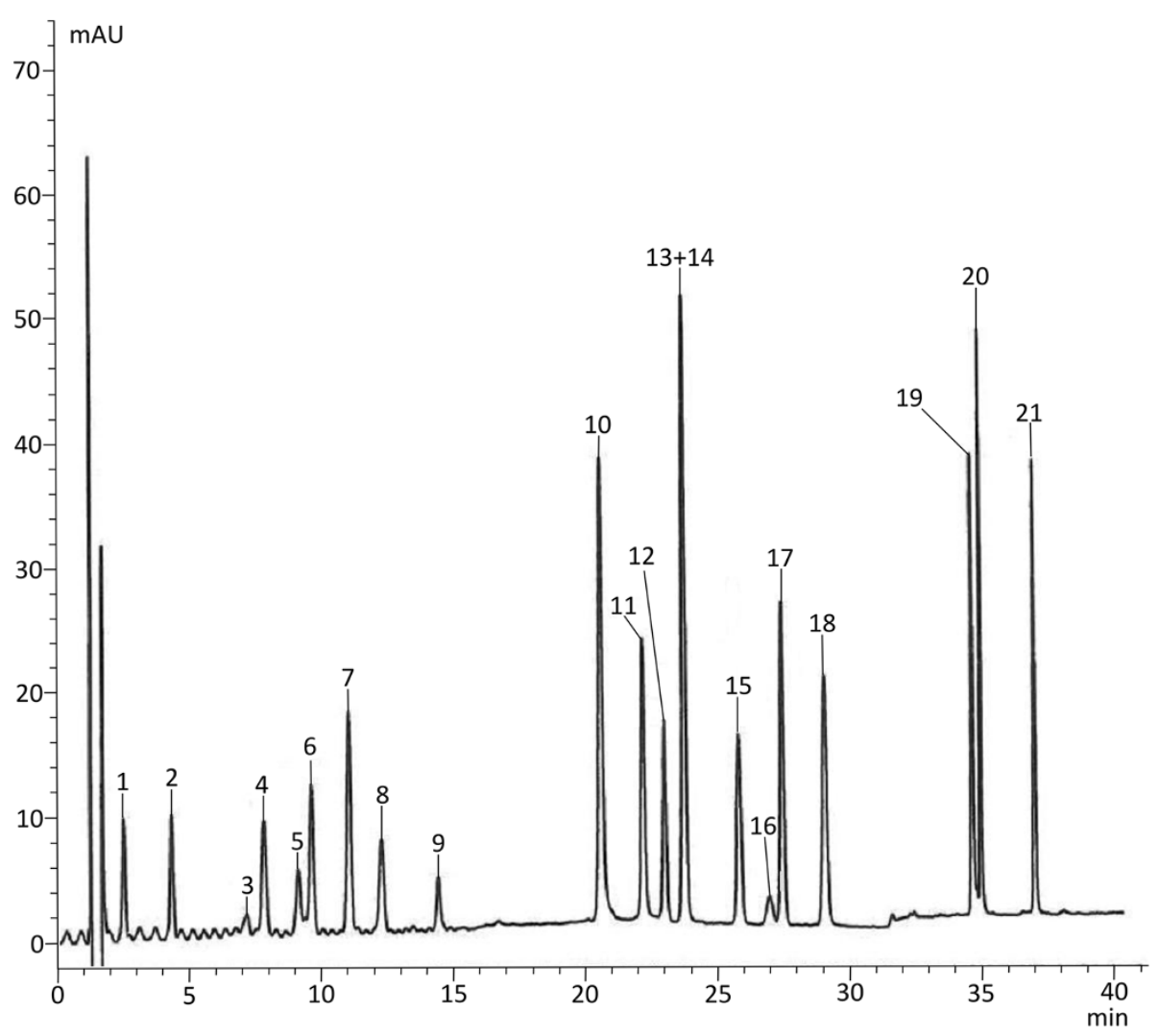

Figure 1 HPLC chromatograms of standard compounds. 1 - gallic acid, 2 - protocatechuic acid, $\mathbf{3}$ - procyanidin $\mathrm{B}_{1}, \mathbf{4}$ - epigallocatechin, $\mathbf{5}$ - catechin, $\mathbf{6}$ - chlorogenic acid, $\mathbf{7}$ - caffeic acid, $\mathbf{8}$ - procyanidin $\mathrm{B}_{2}, \mathbf{9}$ - epicatechin, $\mathbf{1 0}$ - sanguiin H-6, $\mathbf{1 1}$ - ellagic acid, 12 - hyperoside, 13 - isoquercetin, 14 - quercetin 3-O-glucuronide, 15 - kaempferol 3-O-galactoside, 16 - salicylic acid, 17 - quercetin 3-O-rhamnoside, 18 - myricetin, 19 - tiliroside, 20 - quercetin, 21 - kaempferol. 


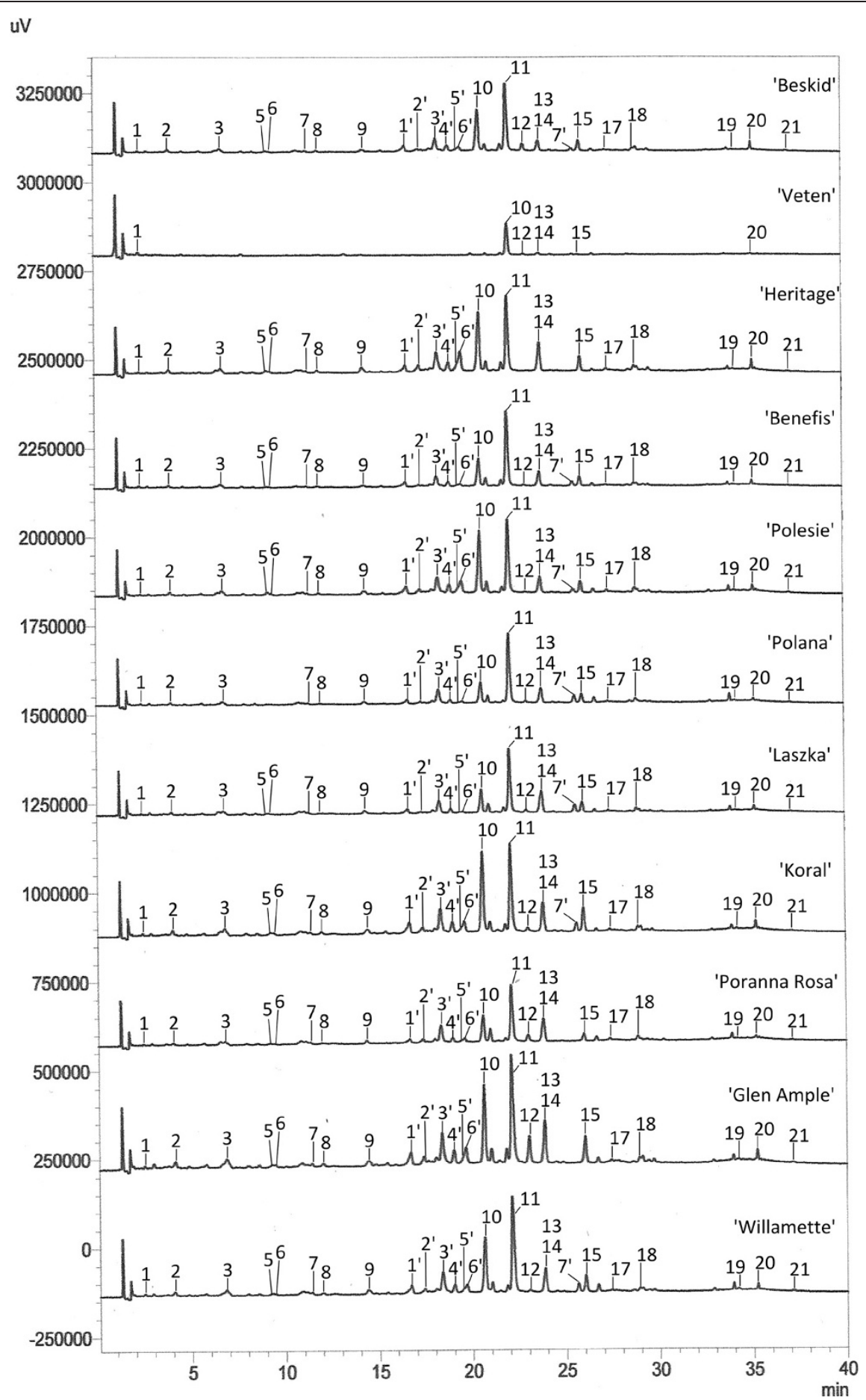

Figure 2 HPLC chromatograms of 11 varieties of $\boldsymbol{R}$. idaeus. $\mathbf{1}$ - gallic acid, $\mathbf{2}$ - protocatechuic acid, $\mathbf{3}$ - procyanidin $\mathrm{B}_{1}, \mathbf{5}$ - catechin, $\mathbf{6}$ - chlorogenic acid, $\mathbf{7}$ - caffeic acid, $\mathbf{8}$ - procyanidin $\mathrm{B}_{2}, \mathbf{9}$ - epicatechin, $\mathbf{1 0}$ - sanguiin H-6, $1 \mathbf{1}$ - ellagic acid, $\mathbf{1 2}$ - hyperoside, $\mathbf{1 3}$ - isoquercetin, 14 - quercetin 3-O-glucuronide, 15 - kaempferol 3-O-galactoside, 17 - quercetin 3-O-rhamnoside, 18 - myricetin, 19 - tiliroside, 20 - quercetin, 21 - kaempferol, 1' - sanguiin H-10, 2' - lambertianin C, 3' - potentilin/casuarictin, 4' - sanguiin H-10, 5' - lambertianin C, 6' - sanguiin H-2, $7^{\prime}$ - unknown quercetin pentoside. Discovery HS C18 $(150 \mathrm{~mm} \times 2.1 \mathrm{~mm} \times 3 \mu \mathrm{m})$, gradient program I. 
Table 2 HPLC-DAD-ESI-MS data of standards and the compounds identified in the shoots of 11 cultivar varieties of R. idaeus

\begin{tabular}{|c|c|c|c|c|c|}
\hline & Compound & $t_{R}(\min )$ & $\lambda_{\max }(\mathrm{nm})$ & Molecular ion $[\mathrm{M}+\mathrm{H}]^{+} /[\mathrm{M}-\mathrm{H}]^{-}(\mathrm{m} / \mathrm{z})$ & Fragment ions $(\mathrm{m} / \mathrm{z})$ \\
\hline 1 & Gallic acid & 2.4 & 214,268 & $171^{+}, 169^{-}$ & - \\
\hline 2 & Protocatechuic acid & 4.2 & 258,293 & $155^{+}, 153^{-}$ & - \\
\hline 3 & Procyanidin $\mathrm{B}_{1}$ & 7.1 & 278 & $579^{+}, 577^{-}$ & - \\
\hline 4 & Catechin & 9.2 & 278 & $291^{+}, 289^{-}$ & - \\
\hline 5 & Chlorogenic acid & 9.8 & 295,327 & $355^{+}, 353^{-}$ & - \\
\hline 6 & Caffeic acid & 11.0 & 294,321 & $181^{+}, 179^{-}$ & - \\
\hline 7 & Procyanidin $B_{2}$ & 12.1 & 278 & $579^{+}, 577^{-}$ & - \\
\hline 8 & Epicatechin & 14.4 & 277 & $291^{+}, 289^{-}$ & - \\
\hline 9 & Sanguiin $\mathrm{H}-6$ & 20.5 & 251 & $1869^{-}$ & {$[934]^{-2},[935]^{-2}$} \\
\hline 10 & Ellagic acid & 22.2 & 252,369 & $303^{+}, 301^{-}$ & - \\
\hline 11 & Hyperoside & 23.0 & 253,350 & $465^{+}, 463^{-}$ & $303^{+}, 301^{-}$ \\
\hline 12 & Isoquercetin & 23.8 & 254,352 & $465^{+}, 463^{-}$ & $303^{+}, 301^{-}$ \\
\hline 13 & Quercetin 3-O-glucuronide & 23.8 & 255,352 & $479^{+}, 477^{-}$ & $303^{+}, 301^{-}$ \\
\hline 14 & Kaempferol 3-O-galactoside & 25.9 & 264,345 & $449^{+}, 447^{-}$ & $287^{+}, 285^{-}$ \\
\hline 15 & Quercetin 3-O-rhamnoside & 27.4 & 254,348 & $449^{+}, 447^{-}$ & $303^{+}, 301^{-}$ \\
\hline 16 & Myricetin & 29.0 & 252,369 & $319^{+}, 317^{-}$ & - \\
\hline 17 & Tiliroside & 34.5 & 266,313 & $595^{+}, 593^{-}$ & - \\
\hline 18 & Quercetin & 35.0 & 253,369 & $303^{+}, 301^{-}$ & - \\
\hline 19 & Kaempferol & 37.1 & 262,362 & $287^{+}, 285^{-}$ & - \\
\hline $1^{\prime}$ & Sanguiin $\mathrm{H}-10$ & 16.7 & 251 & $1567^{-}$ & - \\
\hline $2^{\prime}$ & Lambertianin C & 17.4 & 251 & - & {$[1401]^{-2},[1402]^{-2}$} \\
\hline $3^{\prime}$ & Potentilin/casuarictin & 18.4 & 251 & $935^{-}$ & - \\
\hline $4^{\prime}$ & Sanguiin $\mathrm{H}-10$ & 19.0 & 251 & $1567^{-}$ & - \\
\hline $5^{\prime}$ & Lambertianin C & 19.5 & 251 & - & {$[1401]^{-2},[1402]^{-2}$} \\
\hline $6^{\prime}$ & Sanguiin $\mathrm{H}-2$ & 19.7 & 251 & $1103^{-}$ & - \\
\hline $7^{\prime}$ & Unknown quercetin pentoside & 25.5 & 254,353 & $435^{+}, 433^{-}$ & $303^{+}, 301^{-}$ \\
\hline
\end{tabular}

$t_{R}$ - retention time; $\lambda_{\max }$ - maximum observed absorbance.

Table 3 Concentrations of selected polyphenols in the 11 varieties of $R$. idaeus shoots $(\mathrm{mg} / 100 \mathrm{~g}$ dry weight) $(\mathrm{n}=\mathbf{3})$

\begin{tabular}{|c|c|c|c|c|c|c|c|}
\hline $\begin{array}{l}R . \text { idaeus } \\
\text { variety }\end{array}$ & $\begin{array}{c}\text { Sanguiin } \\
\text { H-6 }\end{array}$ & $\begin{array}{l}\text { Ellagic } \\
\text { acid }\end{array}$ & Epicatechin & Hyperoside & $\begin{array}{c}\text { Isoquercetin and quercetin } \\
3-0-\text { glucuronide }\end{array}$ & Quercetin pentoside* & $\begin{array}{l}\text { Polyphenol } \\
\text { sum }\end{array}$ \\
\hline Willamette & $489.8 \pm 50.8$ & $106.8 \pm 10.9$ & $73.5 \pm 7.4$ & $5.0 \pm 0.5$ & $67.4 \pm 6.8$ & $23.9 \pm 2.5$ & 766.4 \\
\hline Poranna Rosa & $199.6 \pm 20.7$ & $48.4 \pm 4.9$ & $50.0 \pm 5.0$ & $14.7 \pm 1.5$ & $56.7 \pm 5.7$ & - & 369.4 \\
\hline Glen Ample & $394.6 \pm 40.9$ & $77.3 \pm 1.9$ & $42.4 \pm 4.3$ & $32.2 \pm 3.2$ & $47.3 \pm 4.7$ & - & 593.2 \\
\hline Koral & $633.1 \pm 65.6$ & $80.4 \pm 8.2$ & $52.0 \pm 5.2$ & $9.7 \pm 1.0$ & $58.0 \pm 5.8$ & $x$ & 833.1 \\
\hline Laszka & $170.9 \pm 17.7$ & $41.3 \pm 1.0$ & $30.9 \pm 3.1$ & $5.2 \pm 0.5$ & $42.7 \pm 4.3$ & $x$ & 291.0 \\
\hline Polana & $139.2 \pm 14.4$ & $55.8 \pm 5.6$ & $42.9 \pm 4.3$ & $3.3 \pm 0.3$ & $36.6 \pm 3.7$ & $x$ & 277.7 \\
\hline Polesie & $523.6 \pm 54.2$ & $62.9 \pm 6.3$ & $32.7 \pm 3.3$ & $x$ & $29.6 \pm 3.0$ & $x$ & 648.9 \\
\hline Benefis & $195.8 \pm 20.3$ & $71.1 \pm 7.1$ & $16.6 \pm 1.7$ & $4.1 \pm 0.4$ & $36.0 \pm 3.6$ & $x$ & 323.6 \\
\hline Heritage & $481.1 \pm 49.8$ & $63.6 \pm 6.4$ & $85.3 \pm 8.6$ & - & $55.5 \pm 5.6$ & - & 685.4 \\
\hline Veten & $x$ & $26.1 \pm 2.6$ & $10.9 \pm 1.1$ & $x$ & $10.3 \pm 1.0$ & $x$ & 47.3 \\
\hline Beskid & $347.4 \pm 35.9$ & $56.6 \pm 5.7$ & $23.1 \pm 2.3$ & $12,67 \pm 1,27$ & $14.5 \pm 1.5$ & $x$ & 454.2 \\
\hline
\end{tabular}

*calculated as for isoquercetin; $x$ - below the limit of detection. 
Quantitative analysis of polyphenols in raspberry shoots Quantitative analysis of polyphenols in the shoots of the $11 R$. idaeus cultivar varieties was performed using a developed one-dimensional HPLC method (Table 3). Sanguiin $\mathrm{H}-6$ proved to be the dominant polyphenol compound in the shoot extracts with concentrations ranging from $139.2 \mathrm{mg} / 100 \mathrm{~g}$ for 'Polana' variety to $633.1 \mathrm{mg} / 100 \mathrm{~g}$ of dry weight for 'Koral' variety. These values are similar to those observed for raspberries [9]. The analyzed shoots also contained considerable amounts of free ellagic acid (26.1 - $106.8 \mathrm{mg} / 100 \mathrm{~g})$, and the determined values were much more differentiated and often higher than in the fruits, where the mean value was about $32.6 \mathrm{mg} / 100 \mathrm{~g}$ (unpublished results).

The content of epicatechin was established between $10.9 \mathrm{mg} / 100 \mathrm{~g}$ ('Veten') - $85.3 \mathrm{mg} / 100 \mathrm{~g}$ ('Heritage'), and $3.3 \mathrm{mg} / 100 \mathrm{~g}$ ('Polana') - $32.2 \mathrm{mg} / 100 \mathrm{~g}$ ('Glen Ample') for hyperoside. Isoquercetin and quercetin 3-Oglucuronide could not be fully separated in the optimized HPLC-DAD-ESI-MS conditions and their concentrations are presented as a sum (content from $10.3 \mathrm{mg} /$ $100 \mathrm{~g}$ for 'Veten' to $67.4 \mathrm{mg} / 100 \mathrm{~g}$ for 'Willamette').

The shoots of 'Koral,' Polesie,' 'Willamette' and 'Heritage' cultivar varieties proved to be the richest source of sanguiin H-6 (481.1 mg/100 g - $633.1 \mathrm{mg} / 100 \mathrm{~g})$. Ellagic acid was present at the highest concentrations in 'Willamette', 'Koral', 'Glen Ample' and 'Benefis' cultivar varieties $(106.8 \mathrm{mg} / 100 \mathrm{~g}-71.1 \mathrm{mg} / 100 \mathrm{~g})$. The two flavonoids, isoquercetin and quercetin 3-O-glucuronide, were found at the highest concentrations in the shoots of 'Willamette,' 'Koral', 'Poranna Rosa' and 'Heritage' varieties $(67.4 \mathrm{mg} / 100 \mathrm{~g}-55.5 \mathrm{mg} / 100 \mathrm{~g})$. Most of the shoots contained hyperoside amounts between 3.3 and $14.7 \mathrm{mg} / 100 \mathrm{~g}$, with the exception of 'Glen Ample' variety where the content was much higher $(32.2 \mathrm{mg} /$ $100 \mathrm{~g})$. Unidentified quercetin pentoside was present at the highest concentration in the shoots of 'Willamette' cultivar $(23.9 \mathrm{mg} / 100 \mathrm{~g})$ while most of the other varieties contained levels below the limit of detection. Gallic acid, chlorogenic acid, catechin, procyanidin $B_{1}$ and $B_{2}$ were present below the limit of detection. In the stems of 'Willamette,' 'Koral,' 'Polesie' and 'Heritage' varieties overall sum of polyphenols was several times higher than the other varieties $(648.87 \mathrm{mg} / 100 \mathrm{~g}-$ $833.11 \mathrm{mg} / 100 \mathrm{~g}$ ) (Table 3).

\section{Quantitative analysis of polyphenols in $R$. idaeus 'Willamette' dry shoot extract}

The results of the quantitative analysis of the dry shoot extract from $R$. idaeus 'Willamette' are presented in Table 4 . The extract contained about $5 \%$ of sanguiin H-6 and about $1 \%$ of free ellagic acid, which is approximately 10 times higher than in the dried shoots (Table 3). It also contained high amounts of epicatechin, isoquercetin,
Table 4 Concentration of selected polyphenols in the $R$. idaeus 'Willamette' dry shoot extract (mg/100 g dry weight) $(\mathbf{n}=3)$

\begin{tabular}{lc}
\hline Compound & R. idaeus 'Willamette' \\
\hline Sanguiin H-6 & $5256.0 \pm 469.5$ \\
Ellagic acid & $1151.7 \pm 102.9$ \\
Epicatechin & $791.7 \pm 70.7$ \\
Isoquercetin and quercetin 3-O-glucuronide & $717,57 \pm 64,1$ \\
Procyanidin $B_{2}$ & $646.0 \pm 57.7$ \\
Procyanidin B 1 & $299.0 \pm 26.7$ \\
Quercetin pentoside & $252.0 \pm 22.5$ \\
Chlorogenic acid & $177.4 \pm 15.9$ \\
Catechin & $129.3 \pm 11.6$ \\
Gallic acid & $72.2 \pm 6.5$ \\
Hyperoside & $52.3 \pm 4.7$ \\
Polyphenol sum & 9545.2 \\
\hline
\end{tabular}

quercetin 3-O-glucuronide and procyanidins $\mathrm{B}_{1}$ nad $\mathrm{B}_{2}$ (Table 4).

The dry shoot extract proved to be richer in phenolic compounds than the raw plant material and was chosen for biological activity analysis.

\section{Separation of $R$. idaeus shoot polyphenols by 'comprehensive' LCxLC two-dimensional liquid chromatography}

To achieve better resolution and to separate isoquercetin and quercetin 3-O-glucuronide a 'comprehensive' twodimensional LCxLC method was developed (Figure 3). Two-dimensional HPLC is a technique that allows greater values of peak capacity (P) and therefore provides high usefulness in the analysis of complex plant samples [14]. $R$. idaeus 'Willamette' cultivar variety was selected for the analysis as it contained the highest concentrations of isoquercetin and quercetin 3-O-glucuronide.

Initially, the comprehensive LCxLC system was build with two columns: Nucleodur Sphinx RP column $(50 \mathrm{~mm} \times 1 \mathrm{~mm}, 5 \mu \mathrm{m})$ in the first dimension and Chromolith Flash RP-18e $(25 \mathrm{~mm} \times 4.6 \mathrm{~mm})$ column in the second dimension. Nucleodur Sphinx RP column contains silica gel chemically modified with phenyl groups and octadecyl groups in a 1:1 ratio. The separation mechanism is based on both aromatic ring $\pi-\pi$ interactions and hydrophobic interactions (C-18). However, the participation of phenyl groups in separation mechanism decreases with the increase of acetonitrile in the mobile phase. The separation in the first dimension was performed using gradient elution program II, of an increasing concentration of a mixture of TFA:acetonitrile:water $(0.1: 50: 50, \mathrm{v} / \mathrm{v} / \mathrm{v})$, from $10 \%$ to $56 \%$, in a TFA:water mixture $(0.1: 100, \mathrm{v} / \mathrm{v})$. The fractions from the first column were automatically transferred to the second column, in modulation time of $2 \mathrm{~min}$, 


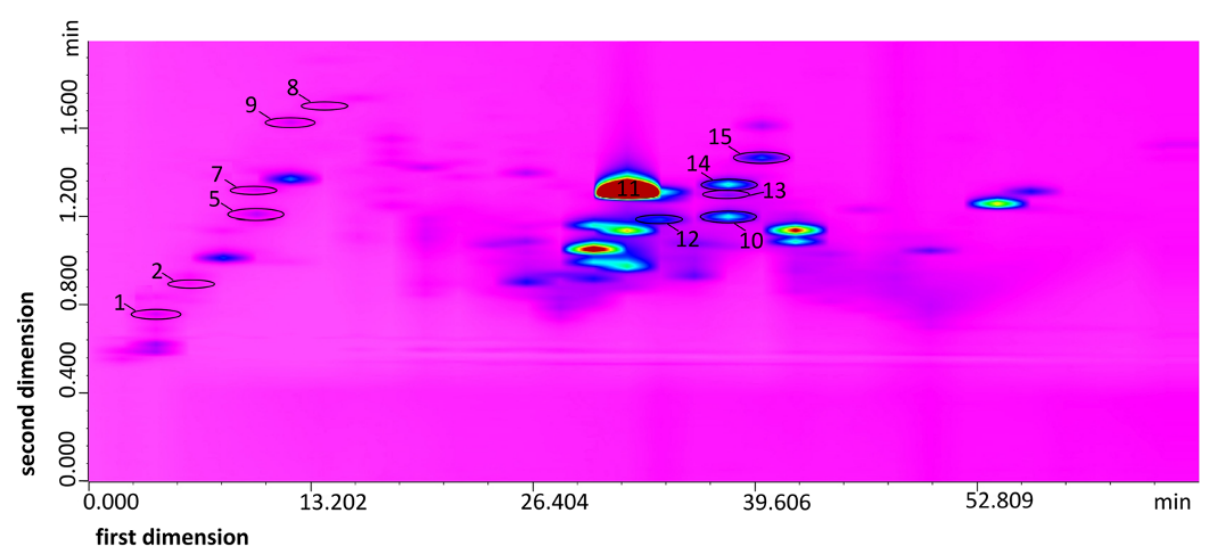

Figure 3 LCxLC chromatogram of the methanol extract from $\boldsymbol{R}$. idaeus 'Willamette' shoots. $\mathbf{1}$ - gallic acid, $\mathbf{2}$ - protocatechuic acid, $\mathbf{5}$ - catechin, $\mathbf{7}$ - caffeic acid, $\mathbf{8}$ - procyanidin $\mathrm{B}_{2}, \mathbf{9}$ - epicatechin, $\mathbf{1 0}$ - sanguiin $\mathrm{H}-6, \mathbf{1 1}$ - ellagic acid, $\mathbf{1 2}$ - hyperoside, $\mathbf{1 3}$ - isoquercetin, 14 - quercetin 3-O-glucuronide, 15 - kaempferol 3-O-galactoside. first dimension - Nucleodur Sphinx RP (50 mm $\times 1 \mathrm{~mm} \times 5 \mu \mathrm{m})$, gradient program II, second dimension - Chromolith Performance (100 $\mathrm{mm} \times 4.6 \mathrm{~mm})$, gradient program III, UV $\lambda=254 \mathrm{~nm}$.

and resolved using gradient elution program III, of an increasing concentration of a mixture of TFA:acetonitrile: water $(0.1: 50: 50, \mathrm{v} / \mathrm{v} / \mathrm{v})$, from 0 to $55 \%$, in a TFA:water solution $(0.1: 100, \mathrm{v} / \mathrm{v})$, at mobile phase flow of $1.5 \mathrm{ml} / \mathrm{min}$. As a further optimization of the LCxLC separation process, a longer column - Chromolith Performance $(25 \mathrm{~mm} \times 4.6 \mathrm{~mm})$ was used in the second dimension instead of Chromolith Flash RP-18e. The same gradient program was maintained but the flow rate of the mobile phase was increased four times (Figure 3). A total of approximately 50 compounds were separated and visible as resolved spots on the obtained LCxLC chromatogram, including isoquercetin and quercetin 3-O-glucuronide (Figure 3). Other separated and identified compounds comprised caffeic acid, gallic acid, protocatechuic acid ellagic acid, catechin, epicatechin, procyanidin $B_{2}$, sanguiin $\mathrm{H}-6$, hyperoside and kaempferol 3-O-galactoside (Figure 3). The peaks corresponding to other compounds, including ellagitannins identified by HPLC-DAD-ESI-MS method were not shown on the LCxLC chromatogram due to their low concentration in the shoot extract.

\section{Antioxidant activity}

The $\mathrm{EC}_{50}$ of the shoot extract from the 'Willamette' variety in the DPPH scavenging assay was established at $19.4 \mu \mathrm{g} / \mathrm{ml}$ and the reducing power in the phosphomolybdenum assay was AAE $427.94 \mathrm{mg} / \mathrm{g}$. These values point out the excellent antioxidative properties of the shoot extract comparable to other plant sources of strong antioxidants, like Potentilla sp. (EC $50-16.9$ to $23.9 \mu \mathrm{g} / \mathrm{ml}$ ) [30], rose $\left(\mathrm{EC}_{50} 12.24 \mu \mathrm{g} / \mathrm{ml}, \mathrm{AAE} 354.87 \mathrm{mg} / \mathrm{g}\right.$ ) [31] representing Rosaceae, or peppermint, thyme, rosemary, and sage from Lamiaceae $\left(\mathrm{EC}_{50} 15-21 \mu \mathrm{g} / \mathrm{ml}\right.$, AAE 156$41 \mathrm{mg} / \mathrm{g}$ ) [32,33]. Raspberry shoot extract was also a much stronger DDPH scavenger than blackberry leaves extracts from three other Rubus spp. which had $\mathrm{EC}_{50}$ values higher than $180 \mu \mathrm{g} / \mathrm{ml}$ [34]. Similarly, some other plants tested with the same methods were several times less potent, e.g. parsley, dill, nettle, senna, and laurel leaves [35] or Iris domestica rhizomes [36]. Raspberry shoots also proved to have two times higher antoxidative capacities than the fruits of the black raspberry and about 10 times higher than red raspberries. The reducing power of the shoots was also about two to three times higher than in the raspberry fruits (unpublished results).

The high sanguiin H-6 content in the shoots is presumed to be the reason for the high antioxidative capacity of the R. idaeus 'Willamette' extract. This is in agreement with the findings about the antioxidative activity of raspberry fruits which confirm that ellagitannin-rich fractions containing sanguiin H-6 obtained from the fruits of $R$. idaeus, display stronger antioxidative capacities than the other, anthocyanin-containing fractions $[7,37,38]$.

Taking into account the possible significance of antioxidants in inhibiting inflammation $[39,40]$ an antiinflammatory assay was performed for the shoots using an in vivo rat model of carrageenan-induced paw edema [41,42]. However no statistically significant anti-inflammatory properties were observed for the shoot extract (data not shown).

\section{Antimicrobial activity}

The results of antimicrobial activity of $R$. idaeus 'Willamette' shoot extract, with ampicillin as a reference, are presented in Table 5. Among the tested strains varied sensitivities to the extracts were observed. Inhibitory activity was observed towards Bacillus subtilis, Clostridium sporogenes, Staphylococcus epidermidis, Neisseria meningitidis, Moraxella catarrhalis and Helicobacter pylori at concentrations ranging from 0.2 to $30 \mathrm{mg} / \mathrm{ml}$. Bactericidal 
Table 5 Antimicrobial activity of $R$. idaeus 'Willamette' shoot extract and ampicillin (mg/ml)

\begin{tabular}{|c|c|c|c|c|}
\hline \multirow[t]{2}{*}{ Bacterial strain } & \multicolumn{2}{|c|}{ R. idaeus 'Willamette' } & \multicolumn{2}{|c|}{ Ampicilin } \\
\hline & MIC & MBC & MIC & MBC \\
\hline Streptococcus group A & 3.75 & 7.5 & $0.3 \times 10^{-3}$ & $0.3 \times 10^{-3}$ \\
\hline Streptococcus group B & 60 & 60 & $0.6 \times 10^{-3}$ & - \\
\hline Streptococcus group G & 15 & 15 & $0.2 \times 10^{-3}$ & - \\
\hline Streptococcus pneumoniae & 7.5 & 7.5 & $0.2 \times 10^{-3}$ & $10 \times 10^{-3}$ \\
\hline Enterococcus faecalis & 120 & 120 & $2.5 \times 10^{-3}$ & $2.5 \times 10^{-3}$ \\
\hline Corynebacterium diphtheriae & 0.06 & 0.06 & $0.2 \times 10^{-3}$ & $0.3 \times 10^{-3}$ \\
\hline Bacillus subtilis & 30 & - & $0.05 \times 10^{-3}$ & $0.3 \times 10^{-3}$ \\
\hline Clostridium sporogenes & 0.2 & - & $1 \times 10^{-3}$ & - \\
\hline Staphylococcus aureus & 0.5 & 1.0 & $0.1 \times 10^{-3}$ & $0.2 \times 10^{-3}$ \\
\hline Staphylococcus epidermidis & 1.9 & - & $0.6 \times 10^{-3}$ & $0.3 \times 10^{-3}$ \\
\hline Neisseria meningitidis & 30 & - & $0.2 \times 10^{-3}$ & $10 \times 10^{-3}$ \\
\hline Moraxella catarrhalis & 0.5 & - & $2.5 \times 10^{-3}$ & $2.5 \times 10^{-3}$ \\
\hline Haemophilus influenzae & - & - & $0.2 \times 10^{-3}$ & $0.2 \times 10^{-3}$ \\
\hline Helicobacter pylori & 7.4 & - & $3.3 \times 10^{-3}$ & $3.3 \times 10^{-3}$ \\
\hline Klebsiella pneumoniae & 60 & 60 & $62.5 \times 10^{-3}$ & - \\
\hline
\end{tabular}

MIC - minimal inhibitory concentration; MBC - minimal bactericidal concentration.

activity was observed for eight bacterial strains at concentrations ranging from as low as $0.06 \mathrm{mg} / \mathrm{ml}$ for Corynebacterium diphtheriae to the maximal tested concentration of $120 \mathrm{mg} / \mathrm{ml}$ for E. faecalis (Table 5).

Interestingly, $C$. diphtheriae proved to be the most sensitive bacterium displaying $\mathrm{MBC}$ values at the lowest tested concentration of $0.06 \mathrm{mg} / \mathrm{ml}$. Staphylococcus aureus was another very sensitive bacterium with both MIC and MBC below $1 \mathrm{mg} / \mathrm{ml}$ ( 0.47 and $0.94 \mathrm{mg} / \mathrm{ml}$ respectively). The extract also displayed strong inhibitory activity towards $C$. sporogenes $(0.23 \mathrm{mg} / \mathrm{ml})$ and $M$. catarrhalis $(0.47 \mathrm{mg} / \mathrm{ml})$. The only bacterium resistant to the shoot extract was $H$. influenzae (Table 5). These results are in accordance with our findings about the antimicrobial properties of raspberry fruit extracts where $C$. diphtheriae, $S$. aureus, $M$. catarrhalis and C. sporogenes were the most sensitive bacteria, although the shoot extract stands out as a more potent inhibitory and bactericidal agent compared to the fruit extracts (accepted paper).

The antimicrobial properties of raspberry shoots have not been studied but the antimicrobial properties of raspberry fruits is the subject of a few papers and their antimicrobial potential is linked mainly to the presence of ellagitannins [38,43-46]. As the raspberry shoot extract is a prospective source of sanguiin H-6 and ellagic acid, these two components are believed to be the ones responsible for its antimicrobial properties.

\section{Cytotoxic activity}

The in vitro cytotoxicity of $R$. idaeus 'Willamette' shoot extract and sanguiin H-6 was tested using human promyelocytic leukemia cell line (HL-60), human cervical cancer cell line (HeLa) and human dermal fibroblasts. The $\mathrm{IC}_{50}$ values for the respective cell lines are presented in Table 6 . The strongest cytotoxic activity of the extract was observed for the HL-60 cells $(110 \mu \mathrm{g} / \mathrm{ml})$. Sanguiin H-6 also displayed distinctive cytotoxic activity in HeLa $(35 \mu \mathrm{g} / \mathrm{ml})$ and HL-60 $(25 \mu \mathrm{g} / \mathrm{ml})$ cell lines. No cytotoxic activity was observed in the human fibroblasts. The cytotoxic activity of the shoot extract can be related to its high sanguiin H-6 content as well. The findings of Ross et al. [37] confirm that the antiproliferative effect of raspberry fruit extracts towards the HeLa cell lines is predominantly associated with the presence of ellagitannins.

\section{Conclusions}

The obtained results are the first to present the chemical composition of the shoots of $R$. idaeus. They show the occurrence of various phenolic compounds, including simple phenols like ellagic acid, and polyphenols such as ellagitannins (sanguiin $\mathrm{H}-6$ ) and flavonoids. The shoots of $R$. idaeus stand out as a valuable and selective source of sanguiin H-6 and ellagic acid and reveal a number of biological properties including antimicrobial, antioxidative and cytotoxic activity.

Table 6 Cytotoxic activity of $R$. idaeus 'Willamette' shoot extract and sanguiin H-6 $\left(\mathrm{IC}_{50}, \mu \mathrm{g} / \mathrm{ml}\right)(\mathrm{n}=3)$

\begin{tabular}{lllc}
\hline & HeLa & HL-60 & Fibroblasts \\
\hline R. idaeus 'Willamette' & $300 \pm 23$ & $110 \pm 5.5$ & - \\
Sanguiin H-6 & $35 \pm 1.4$ & $25 \pm 1.2$ & - \\
\hline
\end{tabular}




\section{Competing interests}

The authors declare that they have no competing interests.

\section{Authors' contributions}

MKB was responsible for the design, analysis and interpretation of data, drafting and revising the manuscript and approving the final version. DG performed the chromatographic analyses and data interpretation. MK was responsible for data interpretation, drafting and revising the manuscript. MM participated in the chromatographic analyses and biological activity experimentation. $\mathrm{RH}$ performed the antimicrobial assay. AM and WK performed the antioxidative assays and statistical analyses. AK performed the cytotoxic assays. All authors read and approved the final manuscript.

\section{Acknowledgements}

We acknowledge the financial support of the Polish Ministry of Science and Higher Education (MNiSzW) in the form of research grant Nr 1790/B/P01/ 2008/35 and quality-promoting subsidy under the Leading National Research Centre (KNOW) program 2012-2017.

\section{Author details}

${ }^{1}$ Department of Pharmacognosy with Medicinal Plants Garden, Faculty of Pharmacy with Subfaculty of Laboratory Medicine, Medical University of Gdańsk, Gen. J. Hallera Str. 107, 80-416 Gdańsk, Poland. Department of Pharmaceutical Microbiology, Faculty of Pharmacy with Subfaculty of Laboratory Medicine, Medical University of Gdańsk, Gen. J. Hallera Str. 107, 80-416 Gdańsk, Poland. '3Department of Pharmaceutical Biology and Botany, Wrocław Medical University, Borowska Str. 211, 50-556 Wrocław, Poland. ${ }^{4}$ Department of Biotechnology, Division of Plant Protection and Biotechnology, Intercollegiate Faculty of Biotechnology, University of Gdańsk and Medical University of Gdańsk, Kładki Str. 24, 80-822 Gdańsk, Poland.

Received: 29 July 2014 Accepted: 9 December 2014

Published: 12 December 2014

\section{References}

1. Hummer KE: Rubus pharmacology: antiquity to the present. HortSci 2010, 45:1587-1591.

2. Rao AV, Snyder DM: Raspberries and human health: a review. J Agric Food Chem 2010, 58:3871-3883.

3. Gulcin I, Topal F, Cakmakci R, Bilsel M, Goren AC, Erdogan U: Pomological features, nutritional quality, polyphenol content analysis, and antioxidant properties of domesticated and 3 wild ecotype forms of raspberries (Rubus idaeus L.). J Food Sci 2011, 76:C585-C593.

4. Jakobek L, Šeruga M, Šeruga B, Novak I, Medvidović-Kosanović M: Phenolic compound composition and antioxidant activity of fruits of Rubus and Prunus species from Croatia. Int J Food Sci Technol 2009, 44:860-868.

5. Lee J, Dossett M, Finn CE: Rubus fruit phenolic research: the good, the bad, and the confusing. Food Chem 2012, 130:785-796.

6. Maatta-Riihinen KR, Kamal-Eldin A, Torronen AR: Identification and quantification of phenolic compounds in berries of Fragaria and Rubus species (Family rosaceae). J Agric Food Chem 2004, 52:6178-6187.

7. Mullen W, McGinn J, Lean MEJ, MacLean MR, Gardner P, Duthie GG, Yokota $T$, Crozier A: Ellagitannins, flavonoids, and other phenolics in red raspberries and their contribution to antioxidant capacity and vasorelaxation properties. J Agric Food Chem 2002, 50:5191-5196.

8. Tanaka T, Tachibana H, Nonaka G, Nishioka I, Hsu FL, Kohda H, Tanaka O: Tannins and related-compounds .122 . New dimeric, trimeric and tetrameric ellagitannins, lambertianins a-D, from rubus-lambertianus seringe. Chem Pharm Bull 1993, 41:1214-1220.

9. Sparzak B, Merino-Arevalo M, Vander Heyden Y, Krauze-Baranowska M, Majdan M, Fecka I, Glod D, Baczek T: HPLC analysis of polyphenols in the fruits of Rubus idaeus L. (Rosaceae). Nat Prod Res 2010, 24:1811-1822.

10. Nowak R: Separation and quantification of tiliroside from plant extracts by SPE/RP-HPLC. Pharm Biol 2003, 41:627-630.

11. Patel AV, Rojas-Vera J, Dacke CG: Therapeutic constituents and actions of Rubus species. Curr Med Chem 2004, 11:1501-1512.

12. Seger C, Sturm S, Stuppner H: Mass spectrometry and NMR spectroscopy: modern high-end detectors for high resolution separation techniquesstate of the art in natural product HPLC-MS, HPLC-NMR, and CE-MS hyphenations. Nat Prod Rep 2013, 30:970-987.
13. Sun J, Lin L, Chen P: Recent applications for HPLC-MS analysis of anthocyanins in food materials. Curr Anal Chem 2013, 9:397-416.

14. Kalili KM, de Villiers A: Recent developments in the HPLC separation of phenolic compounds. J Sep Sci 2011, 34:854-876.

15. Brand-Williams W, Cuvelier ME, Berset C: Use of a free radical method to evaluate antioxidant activity. LWT - Food Sci Technol 1995, 28:25-30.

16. Prieto $P$, Pineda $M$, Aguilar M: Spectrophotometric quantitation of antioxidant capacity through the formation of a phosphomolybdenum complex: specific application to the determination of vitamin $\mathrm{E}$. Anal Biochem 1999, 269:337-341.

17. Wu-Yuan CD, Chen CY, Wu RT: Gallotannins inhibit growth, waterinsoluble glucan synthesis, and aggregation of mutans streptococci. J Dent Res 1988, 67:51-55.

18. Lekogo BM, Coroller L, Mathot AG, Mafart P, Leguerinel I: Modelling the influence of palmitic, palmitoleic, stearic and oleic acids on apparent heat resistance of spores of Bacillus cereus NTCC 11145 and Clostridium sporogenes Pasteur 79.3. Int J Food Microbiol 2010, 141:242-247.

19. Baverud V, Gunnarsson A, Karlsson M, Franklin A: Antimicrobial susceptibility of equine and environmental isolates of Clostridium difficile. Microb Drug Resist 2004, 10:57-63.

20. Doern GV, Jones RN: Antimicrobial susceptibility testing of Haemophilus influenzae, Branhamella catarrhalis, and Neisseria gonorrhoeae. Antimicrob Agents Chemother 1988, 32:1747-1753.

21. Piccolomini R, Di Bonaventura G, Catamo G, Carbone F, Neri M: Comparative evaluation of the $\mathrm{E}$ test, agar dilution, and broth microdilution for testing susceptibilities of Helicobacter pylori strains to 20 antimicrobial agents. J Clin Microbiol 1997, 35:1842-1846.

22. Palikova I, Heinrich J, Bednar P, Marhol P, Kren V, Cvak L, Valentova K, Ruzicka F, Hola V, Kolar M, Simanek V, Ulrichova J: Constituents and antimicrobial properties of blue honeysuckle: a novel source for phenolic antioxidants. J Agric Food Chem 2008, 56:11883-11889.

23. Mosmann T: Rapid colorimetric assay for cellular growth and survival application to proliferation and cyto-toxicity assays. J Immunol Methods 1983, 65:55-63.

24. Beekwilder J, Hall RD, de Vos CHR: Identification and dietary relevance of antioxidants from raspberry. Biofactors 2005, 23:197-205.

25. Gasperotti M, Masuero D, Vrhovsek U, Guella G, Mattivi F: Profiling and accurate quantification of Rubus ellagitannins and ellagic acid conjugates using direct uplc-q-tof hdms and hplc-dad analysis. J Agric Food Chem 2010, 58:4602-4616.

26. Kahkonen M, Kylli P, Ollilainen V, Salminen JP, Heinonen M: Antioxidant activity of isolated ellagitannins from red raspberries and cloudberries. J Agric Food Chem 2012, 60:1167-1174.

27. McDougall G, Martinussen I, Stewart D: Towards fruitful metabolomics: high throughput analyses of polyphenol composition in berries using direct infusion mass spectrometry. J Chromatogr B 2008, 871:362-369.

28. Duke AJ: Handbook of phytochemical constituents of grass herbs and other economic plants. London: CRC; 2000

29. Beekwilder J, Jonker H, Meesters P, Hall RD, van der Meer IM, de Vos CHR: Antioxidants in raspberry: on-line analysis links antioxidant activity to a diversity of individual metabolites. J Agric Food Chem 2005, 53:3313-3320.

30. Wang SS, Wang DM, Pu WJ, Li DW: Phytochemical profiles, antioxidant and antimicrobial activities of three Potentilla species. BMC Complement Altern Med 2013, 13:321.

31. Abdel-Hameed E-SS, Bazaid SA, Salman MS: Characterization of the phytochemical constituents of taif rose and its antioxidant and anticancer activities. Biomed Res Int 2013, 2013:13.

32. Albayrak S, Aksoy A, Albayrak S, Sagdic O: In vitro antioxidant and antimicrobial activity of some Lamiaceae species. Iran J Sci Technol A 2013, 37:1-9.

33. Matkowski A, Piotrowska M: Antioxidant and free radical scavenging activities of some medicinal plants from the Lamiaceae. Fitoterapia 2006, 77:346-353.

34. Gawron-Gzella A, Dudek-Makuch M, Matławska I: Dpph Radical Scavenging Activity and Phenolic Compound Content in Different Leaf Extracts from Selected Blackberry Species. Acta Biologica Cracoviensia Series Botanica 2012, 54:32-38.

35. Albayrak S, Aksoy A, Sagdic O, Albayrak S: Antioxidant and antimicrobial activities of different extracts of some medicinal herbs consumed as tea and spices in Turkey. J Food Biochem 2012, 36:547-554.

36. Wozniak D, Janda B, Kapusta I, Oleszek W, Matkowski A: Antimutagenic and anti-oxidant activities of isoflavonoids from Belamcanda chinensis (L.) DC. Mutat Res 2010, 696:148-153. 
37. Ross HA, McDougall GJ, Stewart D: Antiproliferative activity is predominantly associated with ellagitannins in raspberry extracts. Phytochemistry 2007, 68:218-228.

38. Vuorela S, Kreander K, Karonen M, Nieminen R, Hamalainen M, Galkin A, Laitinen L, Salminen JP, Moilanen E, Pihlaja K, Vuorela H, Vuorela P, Heinonen M: Preclinical evaluation of rapeseed, raspberry, and pine bark phenolics for health-related effects. J Agric Food Chem 2005, 53:5922-5931.

39. Seo K, Yang JH, Kim SC, Ku SK, Ki SH, Shin SM: The antioxidant effects of isorhamnetin contribute to inhibit COX-2 expression in response to inflammation: a potential role of HO-1. Inflammation 2014, 37:712-722.

40. Banerjee P, Jana S, Chakraborty S, Swarnakar S: Inflammation and MMPs in alcohol-induced liver diseases and protective action of Antioxidants. Indian J Biochem Biophys 2013, 50:377-386.

41. Sahin NO, Librowski T: Investigations of anti-inflammatory and analgesic activities of prednisolone solid dispersion prepared with skimmed milk. Pol J Pharmacol 2003, 55:261-265.

42. Winter CA, Risley EA, Nuss GW: Carrageenin-induced edema in hind paw of the rat as an assay for antiiflammatory drugs. Proc Soc Exp Biol Med 1962, 111:544-547.

43. Nohynek LJ, Alakomi HL, Kahkonen MP, Heinonen M, Helander KM, Oksman-Caldentey KM, Puupponen-Pimia RH: Berry phenolics: antimicrobial properties and mechanisms of action against severe human pathogens. Nutr Cancer 2006, 54:18-32.

44. Puupponen-Pimiä R, Nohynek L, Meier C, Kähkönen M, Heinonen M, Hopia A, Oksman-Caldentey KM: Antimicrobial properties of phenolic compounds from berries. J Appl Microbiol 2001, 90:494-507.

45. Puupponen-Pimia R, Nohynek L, Hartmann-Schmidlin S, Kahkonen M, Heinonen M, Maatta-Riihinen K, Oksman-Caldentey KM: Berry phenolics selectively inhibit the growth of intestinal pathogens. J Appl Microbiol 2005, 98:991-1000

46. Rauha JP, Remes S, Heinonen M, Hopia A, Kahkonen M, Kujala T, Pihlaja K, Vuorela $H$, Vuorela P: Antimicrobial effects of Finnish plant extracts containing flavonoids and other phenolic compounds. Int J Food Microbiol 2000, 56:3-12.

doi:10.1186/1472-6882-14-480

Cite this article as: Krauze-Baranowska et al:: Chemical composition and biological activity of Rubus idaeus shoots - a traditional herbal remedy of Eastern Europe. BMC Complementary and Alternative Medicine 2014 14:480

\section{Submit your next manuscript to BioMed Central and take full advantage of:}

- Convenient online submission

- Thorough peer review

- No space constraints or color figure charges

- Immediate publication on acceptance

- Inclusion in PubMed, CAS, Scopus and Google Scholar

- Research which is freely available for redistribution 